\title{
Fabrication of Porous Silicon Oxycarbide Ceramics by Foaming Polymer Liquid and Compression Molding
}

\author{
高分子液体の泡立てと圧縮金型成形による \\ 多孔質シリコンオキシカーバイドセラミックスの作製
}

\author{
Young-Wook KIM, ${ }^{\dagger}$ Kyoung-Ho LEE, ${ }^{*}$ Sung-Hee LEE and Chul B. PARK* \\ Department of Materials Science and Engineering, The University of Seoul, Seoul 130-743, Korea \\ * Microcellular Plastics Manufacturing Laboratory, Department of Mechanical and Industrial Engineering, University of Toronto, \\ Toronto, Canada, M5S $3 G 8$
}

\begin{abstract}
Porous silicon oxycarbide ( $\mathrm{SiOC}$ ) ceramic with a porosity of $60 \%$ and a cell density greater than $10^{4}$ cells/ $\mathrm{cm}^{3}$ was fabricated from a mixture of a polysiloxane and a chemical blowing agent by simple compression molding and subsequent pyrolysis of the polysiloxane. Optimization of processing parameters and selection of appropriate chemical blowing agent for each system will provide a simple processing route for producing highly porous ceramics.

[Received July 8, 2003; Accepted July 24, 2003]
\end{abstract}

Key-words : Porous ceramic, Compression molding, Preceramic polymer, Silicon oxycarbide

\section{Introduction}

The increasing interest in porous materials has been associated with their unique properties, such as low density, low thermal conductivity, high permeability, high surface area, high thermal shock resistance and high specific strength. ${ }^{1)-3)}$ These characteristics make them good candidates for both structural and functional applications, such as thermal insulators, refractory linings for furnaces, filters, catalysts, and porous implants in the area of biomaterials. Closed-cell materials are needed for insulators and refractory linings whereas open-cell materials are required for filters, catalysts and implants.

Various processing routes have been proposed for the production of porous ceramics: (1) replication of polymer foams by impregnation with ceramic slurries;4)-6) (2) direct foaming of ceramic slurries ${ }^{7)-10)}$ or of sol-gel solutions; ${ }^{11,12)}$ and (3) partial sintering of ceramics;13),14) (4) incorporation of organic phases that are then eliminated during firing; ${ }^{15}$ and (5) foaming of preceramic polymers using $\mathrm{CO}_{2}$ followed by pyrolysis. ${ }^{16), 17)}$ The first two approaches lead mainly to cellular pores varying from $50 \mu \mathrm{m}$ to $5 \mathrm{~mm}$. In contrast, the other three approaches typically produce cellular pores varying from approximately $2 \mathrm{~nm}$ to $30 \mu \mathrm{m}$.

Compression molding is a well-known forming technology for thermosets and thermoplastic polymers. In fact, compression molding is the most common method of processing thermoset polymers. Compression molding has a several advantages such as short cycle time (typically 1-6 min), high volume production and high quality surfaces. The compression molding might also be applied to process porous ceramics from preceramic polymers because preceramic polymer behaves like polymeric materials.

This work introduces a new processing route for the fabrication of porous ceramics from preceramic polymers by compression molding. The strategy for making porous ceramics involves: (i) dispersing a chemical blowing agent (designated as CBA) in preceramic polymers, (ii) foaming in compression molding, and (iii) transforming the porous preceramic polymers into porous ceramics by pyrolysis.

\section{Experimental procedure}

The preceramic polymer used was a kind of polysiloxane (YR3370, GE Toshiba Silicones Co., Ltd., Tokyo). Its pyrolysis in inert atmosphere yields a $\mathrm{Si}_{x} \mathrm{O}_{y} \mathrm{C}_{z}$ ceramic, with a weight loss of about 19\%. A low temperature endothermic blowing agent (SAFOAM-FP, Reedy International Corporation, Keyport, NJ, USA) was used as a chemical blowing agent. Its average particle size is $12 \mu \mathrm{m}$ and it liberates $\sim 100 \pm 10 \mathrm{~cm}^{3} / \mathrm{g}$ of $\mathrm{CO}_{2}$ at temperatures ranging from approximately $125^{\circ} \mathrm{C}$ to $165^{\circ} \mathrm{C}$. YR3370 was dry-blended with 5 mass\% SAFOAM-FP as a blowing agent and 1.2 mass\% benzoyl peroxide as a cross-linking agent. The blended powder was compression-molded into disks $(100 \mathrm{~mm}$ diameter $\times 5 \mathrm{~mm}$ thick) at $125^{\circ} \mathrm{C}$ for $1 \mathrm{~min}$. The temperature was selected such that it was higher than the softening temperature $\left(109^{\circ} \mathrm{C}\right)$ of the polysiloxane, allowing foaming. Due to the lower decomposition rate of $\mathrm{CBA}$ at $125^{\circ} \mathrm{C}$ (a relatively low temperature compared to the suggested decomposition temperature), the in-mold residence time of polysiloxane is longer in order for the CBA decomposition to be completed. The molded porous preceramic specimens were further cross-linked by heating at $78^{\circ} \mathrm{C}$ for $24 \mathrm{~h}$, followed by heating at $88^{\circ} \mathrm{C}$ for $6 \mathrm{~h}$ and heating at $180^{\circ} \mathrm{C}$ for $2 \mathrm{~h}$ in air. The molded preceramic specimens, then, were pyrolyzed at $1100^{\circ} \mathrm{C}$ for $1 \mathrm{~h}$ with a heating rate of $1^{\circ} \mathrm{C} / \mathrm{min}$ in nitrogen. The microstructures of as molded and the pyrolyzed specimens were observed by scanning electron microscopy (SEM). The cell density of the obtained porous materials was measured by counting the number of cells in two-dimensional image on the microstructure and by converting it to 3-dimension for both preceramic and ceramic states. ${ }^{17)}$

\section{Results}

Figure 1 shows typical microstructures of (a) as-molded and (b) pyrolyzed specimens obtained in this study. The morphology of cells in the molded specimen shows closed cells, whereas the morphology in the pyrolyzed specimen a mixture of closed and open cells. The average cell sizes of the as-molded and the pyrolyzed specimens were $\sim 650 \mu \mathrm{m}$ and $\sim 400 \mu \mathrm{m}$, respectively. The decrease in cell size after pyrolysis was due to the shrinkage during pyrolysis. The cell densities of the molded and the pyrolyzed specimens with respect to the unfoamed original volume were $\sim 6.4 \times$ $10^{4}$ cells $/ \mathrm{cm}^{3}$ and $\sim 9.0 \times 10^{4}$ cells $/ \mathrm{cm}^{3}$, respectively. The difference in the cell density is within the range of a typical measurement error. These results indicate that the original 

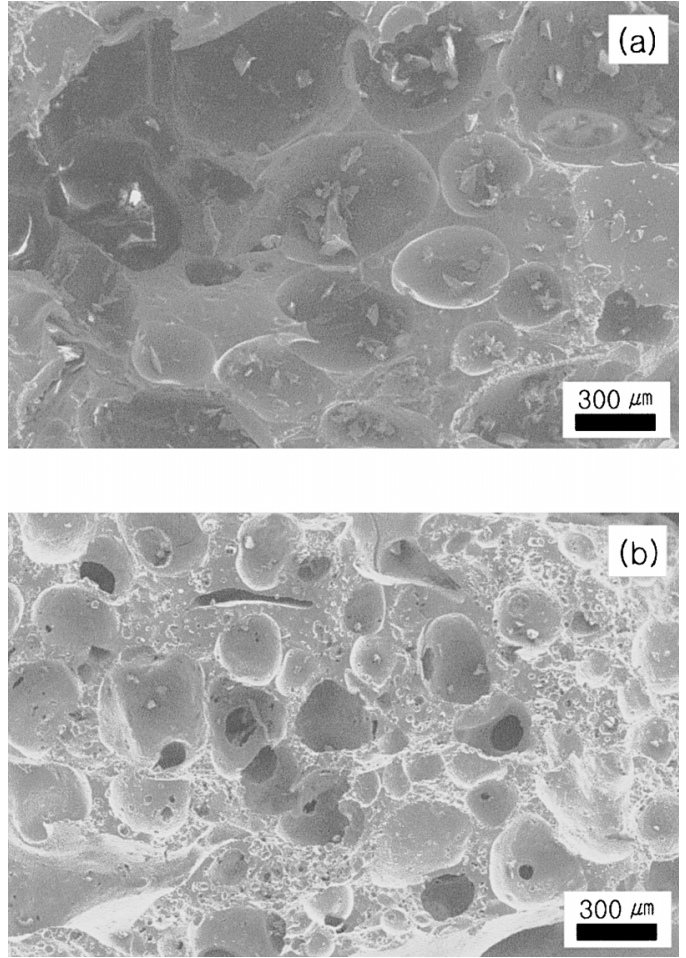

Fig. 1. Typical fracture surfaces of (a) as-molded and (b) pyrolyzed SiOC specimens.

pore structure has been kept during pyrolysis process. The porosities of the foamed preceramic and the pyrolyzed ceramic specimens were 67 and $60 \%$, respectively.

The present results demonstrate the feasibility of producing highly porous ceramics by compression molding. Optimization of processing parameters and selection of appropriate chemical blowing agent for each system will provide a new, simple processing route for producing porous ceramics.

Acknowledgment One of authors (Y.-W. Kim) gratefully acknowledge helpful discussions with Professor Masaki Narisawa at Osaka Prefecture University in Japan. This work was supported by the Korea Research Foundation under Grant No. KRF-2002013-E00094.

\section{References}

1) Bhaduri, S. B., Adv. Performance Mater., Vol. 1, pp. 205-220 (1994).

2) Sheppard, L. M., Ceram. Trans., Vol. 31, pp. 3-23 (1993).

3) Woyansky, J. S., Scott, C. E. and Minnear, W. P., Am. Ceram. Soc. Bull., Vol. 71, pp. 1674-1682 (1992).

4) Minnear, W. P., Ceram. Trans., Vol. 26, pp. 146-156 (1992).

5) Lange, F. F. and Miller, K. T., Adv. Ceram. Mater., Vol. 2, pp. 827-831 (1987).

6) Bhaduri, S. B. and Qian, Z. B., J. Mater. Synth. Proc., Vol. 3, pp. 361-369 (1995).

7) Powell, S. J. and Evans, J. R. G., Mater. Manuf. Process., Vol. 10, pp. 757-771 (1995).

8) Ortega, F. S., Sepulveda, P., Innocentini, M. D. M. and Pandolfelli, V. C., Am. Ceram. Soc. Bull., Vol. 80, pp. 37-42 (2001).

9) Colombo, P. and Modesti, M., J. Am. Ceram. Soc., Vol. 82, pp. 573-578 (1999).

10) Colombo, P., Griffoni, M. and Modesti, M., J. Sol-Gel Sci. Tech., Vol. 13, pp. 195-199 (1998).

11) Fujiu, T., Messing, G. L. and Huebner, W., J. Am. Ceram. Soc., Vol. 73, pp. 85-90 (1990).

12) Wu, M. and Messing, G. L., J. Am. Ceram. Soc., Vol. 73, pp. 3497-3499 (1990).

13) Fukasawa, T., Deng, Z. Y., Ando, M., Ohji, T. and Kanzaki, S., J. Am. Ceram. Soc., Vol. 85, pp. 2151-2155 (2002).

14) Inagaki, Y., Kondo, N. and Ohji, T., J. Eur. Ceram. Soc., Vol. 22, pp. 2489-2494 (2002).

15) Kormarneni, S., Pach, L. and Pidugu, R., Mater. Res. Soc. Symp. Proc., Vol. 371, pp. 285-290 (1995).

16) Kim, Y.-W., Kim, S. H., Xu, X., Choi, C. H., Park, C. B. and Kim, H. D., J. Mater. Sci. Lett., Vol. 21, pp. 1667-1669 (2002).

17) Kim, Y.-W. and Park, C. B., Comp. Sci. and Tech., accepted for publication (2003) 